\title{
Keberhasilan Sambung Pucuk Durian (Durio zibethinus) Lokal Aceh Akibat Perlakuan Cara dan Lama Penyimpanan Batang Atas
}

\author{
Nasrun Liwanza ${ }^{1}$, Muksalmina $^{2}$, Ismadi $^{2}$, Rd. Selvy Handayani ${ }^{2 *}$ \\ ${ }^{1}$ Mahasiswa Program Magister Agroekoteknologi Fakultas Pertanian Universitas Malikussaleh, Aceh Utara \\ ${ }^{2}$ Program Magister Agroekoteknologi Fakultas Pertanian, Universitas Malikussaleh Aceh Utara \\ Kampus Unimal, Cot Teungku Nie Reuleut, Kecamatan Muara Batu, Kabupaten Aceh Utara, Indonesia \\ *Email korespondensi: selvy@unimal.ac.id
}

\begin{abstract}
ABSTRAK
Sambung pucuk merupakan salah satu teknik penyambungan yang biasa digunakan pada perbanyakan tanaman durian. Kendala utama pada saat penyambungan adalah jarak antara tempat pembibitan untuk pengerjaan sambungan (sumber batang bawah) dan pohon induk unggul lokal Aceh (sumber batang atas). Tempat penyambungan dan pohon induk biasanya berjauhan, bahkan bisa sampai berbeda pulau. Selain itu, jumlah tanaman yang akan disambungkan sangat banyak sehingga sulit diselesaikan dalam waktu satu hari. Oleh karena itu batang atas harus dikemas kembali dan disimpan, karena tertundanya waktu penyambungan. Tujuan penelitian ini adalah untuk mengetahui pengaruh cara dan lama waktu penyimpanan batang atas terhadap keberhasilan sambung pucuk tanaman durian. Penelitian ini menggunakan Rancangan Acak Kelompok (RAK) dua faktor. Faktor pertama adalah cara penyimpanan batang atas $(\mathrm{P})$ terdiri dari 2 jenis yaitu batang atas tanpa dibungkus kertas koran (P1), dan batang atas yang dibungkus kertas koran (P2). Faktor kedua adalah lama penyimpanan batang atas (L) terdiri dari 6 taraf yaitu batang atas langsung disambungkan (L0), disimpan satu hari (L1), disimpan dua hari (L2), disimpan tiga hari (L3), disimpan empat hari (L4), dan disimpan lima hari (L5). Hasil penelitian menunjukkan bahwa faktor cara penyimpanan batang atas (dibungkus dan tidak dibungkus koran) secara tunggal tidak memberikan pengaruh di semua peubah yang diamati. Faktor lama penyimpanan batang atas secara tunggal berpengaruh terhadap pertumbuhan bibit durian hasil sambungan. Batang atas dapat disimpan paling lama hanya 2 hari. Semakin lama batang atas disimpan sebelum disambungkan, akan menurunkan tingkat keberhasilan sambungan. Kombinasi perlakuan antara cara dan lama penyimpanan batang atas tidak memberikan pengaruh di semua peubah yang diamati.
\end{abstract}

Kata kunci: batang bawah, bibit, pecah tunas, nekrotik

\begin{abstract}
Top grafting is one of the techniques commonly used in durian plant propagation. The main problem with grafting is the distance between the nursery (rootstock source) and Aceh superior Durian parent tree (source of scion). The location of grafting and the parent tree are usually far apart, some are even on different islands. Moreover, the number of plants that will be grafted is so large that it is difficult to complete in one day. Therefore, the scion must be repackaged and stored due to the delay in grafting time. The purpose of this research was to determine the effect on the method and duration of scion storage on the success of grafting durian plants. This research used a two-factor Randomized Block Design (RBD). The first factor is the storage method of the scion (P) which consists of 2 types; the scion that is not wrapped in the newsprint (P1) and the one that is wrapped in the newsprint (P2). The second factor was the scion storage time (L) which consisted of 6 levels; the scion which was directly grafted (L0), stored for one day (L1), stored for two days (L2), stored for three days (L3), stored for four days ( L4) and stored for five days (L5). The results showed that the scion storage method (wrapped and not wrapped) did not affect all the observed variables. The scion storage time affects the growth of durian seedlings resulting from the grafting. The scion can be stored for a maximum of only 2 days. The longer the scion is stored before grafting, the lower the success rate of grafting. The combination between the method and scion storage time had no effect on all observed variables.
\end{abstract}

Keywords: rootstock, seedling, bud burst, necrotic 


\section{PENDAHULUAN}

Buah durian (Durio zibethinus) mempunyai rasa yang sangat enak sehingga mendapat julukan King of The Fruit. Buah durian di beberapa daerah dikenal dengan nama yang berbeda-beda, yaitu duren (Jawa, Betawi, Gayo), kadu (Sunda), duriang (Manado), duliang (Toraja), dan rulen (Pulau Suram Timur) (Rosyidah, 2010).

Buah durian, selain karena rasanya yang sangat lezat dan aromanya yang harum, ternyata buah durian merupakan salah satu makanan sehat karena memiliki banyak manfaat bagi kesehatan tubuh (Sumarianto, 2012). Durian Indonesia, khususnya lokal Aceh tidak kalah enaknya dengan durian yang ada di negara lain. Aceh memiliki potensi durian unggul yang tinggi, yang tersebar di seluruh daerah propinsi Aceh, terutama di Aceh Utara.

Perbanyakan tanaman durian secara vegetatif terutama dengan sistem penyambungan (grafting) merupakan alternatif yang tepat untuk dilakukan pada tanaman durian. Teknik ini sering digunakan pada tanaman durian karena dapat meningkatkan produktivitas tanaman (Rosyidah, 2010).

Sambung pucuk merupakan salah satu teknik penyambungan yang biasa digunakan pada perbanyakan tanaman durian. Sambung pucuk merupakan penggabungan batang bawah dengan batang atas dari varietas tanaman yang berbeda sedemikian rupa sehingga terjadi penyatuan kambium batang bawah dan kambium batang atas sehingg akan terus tumbuh membentuk tanaman baru. Teknik ini mudah dilakukan dan petani biasa melakukannya di kebun sendiri (Ermansyah, 2012).

Kendala utama pada saat penyambungan adalah jarak antara tempat pembibitan untuk pengerjaan sambungan (sumber batang bawah) dan pohon induk unggul lokal Aceh (sumber batang atas). Tempat penyambungan dan pohon induk biasanya berjauhan, bahkan bisa sampai berbeda pulau. Selain itu, jumlah tanaman yang akan disambungkan sangat banyak sehingga sulit diselesaikan dalam waktu satu hari. Oleh karena itu batang atas harus dikemas kembali dan disimpan karena tertundanya waktu penyambungan (Sjaefuddin dan Abdurahman, 2001).

Kendala jarak dan penundaan waktu penyambungan ini dapat diatasi dengan cara menyimpan batang atas dalam media pembungkus agar kelembaban dan kesegaran batang atas dapat terjaga dengan baik. Hal ini dilakukan karena batang atas yang digunakan untuk penyambungan tanaman harus dalam keadaan segar. Penyimpanan batang atas dalam kertas mampu menahan penurunan daya tumbuh batang atas tersebut (Jamnah, 1996).

Penelitian berbagai jenis tanaman lokal unggulan telah mulai dilakukan tim penelitian tanaman buah Fakultas Pertanian Universitas Malikussaleh. Jenis tanaman yang sudah diteliti untuk mengungkap keunggulan tanaman lokal Aceh adalah pada tanaman durian (Handayani \& Ismadi 2017; Handayani \& Ismadi 2018; Handayani et al. 2019), manggis (Handayani et al., 2017), dan alpukat (Ismadi et al. 2018); (Ismadi et al. 2019),

Penelitian ini akan membahas mengenai pemecahan masalah penyambungan tanaman durian, dengan cara pengemasan dan penyimpanan batang atas sebelum disambungkan. Tujuan penelitian ini adalah untuk mengetahui pengaruh cara dan waktu penyimpanan batang atas terhadap keberhasilan sambung pucuk tanaman durian.

\section{METODE PENELITIAN}

Penelitian dilaksanakan di Desa Teungoh Lhoksukon Barat Kecamatan Lhoksukon Kabupaten Aceh Utara. Pelaksanaan penelitian dilakukan dibulan Februari-Juli 2019. Bahanbahan yang digunakan adalah batang atas unggul lokal yang diambil dari kebun masyarakat di Desa Teungoh Kecamatan Lhoksukon Kabupaten Aceh Utara. Batang bawah yang digunakan berasal dari biji sapuan Geudong Kabupaten Aceh Utara.

Penelitian ini menggunakan Rancangan Acak Kelompok (RAK) dua faktor. Faktor pertama adalah cara penyimpanan batang atas $(\mathrm{P})$ terdiri dari 2 jenis yaitu batang atas tanpa dibungkus kertas koran (P1), dan batang atas yang dibungkus kertas koran (P2). Faktor kedua adalah lama penyimpanan batang atas (L) terdiri dari 6 taraf yaitu batang tanpa penyimpanan/ langsung disambungkan (L0), disimpan satu hari (L1), disimpan dua hari (L2), disimpan tiga hari (L3), disimpan empat hari (L4), dan disimpan lima hari (L5). Penelitian ini terdiri dari 12 kombinasi perlakuan, yang diulang $5 \mathrm{kali}$, sehingga terdapat 60 unit percobaan. Setiap unit percobaan terdiri atas 6 tanaman, sehingga total tanaman sambungan adalah 360 .

Pembibitan batang bawah dilakukan pada tempat pesemaian benih. Media pesemaian adalah sekam, abu sekam dan tanah top soil dengan volume perbandingan 2:1:1 (v/v). Pembibitan batang bawah disiram setiap hari yang dilakukan 
pada sore hari dan dilakukan penyiangan setiap dua minggu.

Penggunaan batang atas yaitu berupa tunas durian dari pohon induk unggul lokal Aceh yang diperoleh dari kebun masyarakat Desa Teungoh Lhoksukon Barat Kecamatan Lhoksukon Kabupaten Aceh Utara. Tunas batang atas yang dipilih adalah yang sedang dalam keadaan dorman dengan ukuran panjang tunas 15 $\mathrm{cm}$. Kriteria batang atas yang dipilih adalah memiliki sifat rasa buah manis, daging tebal, dan berbuah lebat.

Batang bawah durian yang digunakan adalah bibit batang bawah yang berumur 3 bulan. Penyambungan dilakukan dengan metode sambung celah $\mathrm{V}$, kemudian dilakukan pengikatan menggunakan plastik elastis di daerah sambungan. Bibit durian hasil sambungan dipelihara di dalam sungkup plastik majemuk yang diletakkan di bawah naungan. Untuk menghindari serangan cendawan maka alas tempat bibit durian sambungan ditaburi sekam. Pencegahan serangan jamur dilakukan dengan melakukan penyemprotan fungisida. Kegiatan penyungkupan bibit durian hasil sambungan berlangsung selama satu bulan. Penyiraman dilakukan di dalam sungkup dua hari sekali dengan menggunakan handsprayer. Data dianalisis dengan analisis ragam dengan uji $\mathrm{F}$ taraf 5\%, dan uji lanjut dengan menggunakan Uji Jarak Berganda Duncan (UJBD) pada taraf 5\%.

\section{HASIL DAN PEMBAHASAN}

\section{Hasil}

Berdasarkan hasil sidik ragam didapatkan bahwa tidak terdapat interaksi antara faktor cara peyimpanan batang atas (P) dan lama penyimpanan batang atas (L) di semua peubah yang diamati. Pengaruh masing-masing faktor secara tunggal hanya terlihat pada faktor lama penyimpanan batang atas (L). Hasil uji lanjut persentase keberhasilan sambungan dan waktu pecah tunas akibat cara dan lama penyimpanan batang atas disajikan pada Tabel 1 .

Tabel 1 menunjukkan bahwa faktor perlakuan cara penyimpanan batang atas secara tunggal tidak memberikan pengaruh terhadap persentase keberhasilan sambungan durian. Faktor lama penyimpanan batang atas secara tunggal berpengaruh pada persentase keberhasilan sambungan dan waktu pecah tunas. Batang atas yang disimpan selama 0 sampai 2 hari (L0, L1, L2) ternyata menyebabkan keberhasilan sambungan lebih tinggi dibandingkan perlakuan lainnya.
Pada peubah pertambahan panjang tunsa batang atas, hasil analisis ragam menunjukkan bahwa tidak ada interaksi antara kedua faktor. Faktor yang memberikan pengaruh terhadap panjang tunas batang atas secara tungal adalah lama penyimpanan batang atas (L). Hasil uji lanjut pengaruh cara dan lama penyimpanan batang atas secara tunggal terhadap pertambahan panjang tunas batang atas disajikan pada Tabel 2 .

Tabel 2 menunjukkan bahwa perlakuan cara penyimpanan batang atas secara tunggal tidak memberikan pengaruh yang nyata terhadap pertambahan panjang tunas batang atas. Pengaruh yang sangat nyata terdapat pada faktor lama penyimpanan batang atas. Penyimpanan batang atas selama 0 hari ternyata menghasilkan panjang tunas batang atas terbaik dibandingkan perlakuan lainnya.

Hasil uji $\mathrm{F}$ menunjukkan bahwa tidak adanya interaksi antara cara dan lama penyimpanan batang atas terhadap pertambahan diameter batang atas. Pengaruh faktor perlakuan secara tunggal hanya terdapat pada perlakuan lama penyimpanan batang atas (L). Data hasil uji lanjut pengaruh perlakuan cara dan lama penyimpanan batang atas secara tunggal terhadap pertambahan diameter batang atas disajikan pada Tabel 3 .

Tabel 3 menunjukkan pengaruh faktor tunggal perlakuan cara dan lama penyimpanan batang atas terhadap diameter batang atas. Cara penyimpanan batang atas secara tunggal tidak menyebabkan perbedaan pada peubah diameter batang atas. Lama penyimpanan batang atas secara tunggal memberikan pengaruh pada peubah diameter batang atas. Secara umum, perlakuan penyimpanan batang atas selama 0 sampai 2 hari menyebabkan diameter batang atas lebih baik, namun diameternya akan menurun disimpan dalam waktu yang lebih lama.

Pada peubah jumlah daun, hasil uji F pada analisis ragam menunjukkan bahwa tidak adanya interaksi antara cara dan lama penyimpanan batang atas terhadap pertambahan jumlah daun tanaman durian. Data hasil uji lanjut pengaruh perlakuan cara dan lama penyimpanan batang atas secara tunggal terhadap pertambahan jumlah daun disajikan pada Tabel 4 .

Tabel 4 menunjukkan bahwa perlakuan cara penyimpanan batang atas secara tunggal tidak memberikan pengaruh terhadap peubah jumlah daun 0 sampai 150 HSS. Faktor lama penyimpanan batang atas secara tunggal ternyata memberikan pengaruh pada peubah jumlah daun di 150 HSS. Bibit durian yang berasal dari batang atas yang disimpan selama 0 sampai 4 hari ternyata memiliki jumlah daun yang sama secara statistik. 
Jumlah daun terendah hanya ada pada perlakuan lama penyimpanan batang atas selama 5 hari.

\section{Pembahasan}

Berdasarkan hasil analisis ragam bahwa tidak terjadi interaksi antara perlakuan cara dan lama penyimpanan batang atas pada semua peubah yang diamati. Perlakuan cara penyimpanan batang atas (faktor pertama) secara tunggal juga tidak memberikan pengaruh di semua peubah yang diamati. Faktor perlakuan yang memberikan pengaruh pada peubah yang diamati adalah faktor kedua yaitu lama penyimpanan batang atas (Tabel 1 sampai 6).

Perlakuan cara penyimpanan batang atas secara tunggal tidak memberikan pengaruh di semua peubah yang diamati. Hal ini dikarenakan bahan pembungkus yang digunakan mampu berfungsi dengan baik untuk menjaga kelembaban batang atas sehingga batang atas tidak layu.

Perlakuan lama penyimpanan batang atas secara tunggal memberikan pengaruh pada semua peubah yang diamati, kecuali pada peubah pertambahan diameter batang bawah. Semakin lama batang atas disimpan sebelum disambungkan, maka pertumbuhan bibit hasil sambungan akan semakin menurun.

Batang atas yang disimpan lama sebelum disambungkan akan menghasilkan lebih banyak sel-sel mati di sekitar daerah luka. Hal ini akan menyebabkan semakin banyak terjadinya jaringan nekrotik yang dapat memperlambat proses penyembuhan luka dan dapat menghambat keberhasilan bibit sambungan (Handayani et al., 2013)

Penyimpanan batang atas yang lama berpengaruh terhadap kesegaran batang atas dan menurunnya kadar air pada batang atas, sehingga menyebabkan viabilitas atau kemampuan hidup batang saat penyambungan menjadi menurun (Manubelu, 2011). Selama penyimpanan proses transpirasi pada batang atas tetap terjadi, kadar air yang terdapat pada batang atas akan hilang seiring dengan terjadinya proses transpirasi. Oleh karena itu kemampuan batang atas untuk hidup semakin menurun karena banyak kadar air yang hilang (Manubelu, 2011).

Cadangan makanan dan kadar air yang terdapat pada batang atas akan digunakan untuk proses metabolisme dan respirasi seiring dengan lamanya penyimpanan, sehingga cadangan makanan dan kadar air akan hilang. Semakin lama proses respirasi berlangsung semakin banyak cadangan makanan yang digunakan sehingga persentase sambung yang hidup akan berkurang.
Sebagai organisme hidup batang atas melakukan proses respirasi metabolisme dan respirasi untuk mempertahankan kelangsungan hidupnya. Batang atas akan melakukan proses respirasi yang tidak begitu membahayakan dalam keadaan normal, akan tetapi proses respirasi akan berubah seiring dengan berubahnya faktor lingkungan, kondisi ini disebut dengan proses pelepasan energi (Manubelu, 2011). Batang atas harus segera digunakan untuk sambung, karena penundaan penyambungan lebih dari satu hari sejak pengambilan batang atas akan menurunkan presentase bibit jadi dan memperlambat pertumbuhan (Lasimin, 2009).

Keberhasilan sambungan memerlukan kompatibilitas antara batang atas dan batang bawah (Anindiawati, 2011). Posisi kesesuaian (matching) lingkaran jaringan pembuluh gabungan (joint vascular bundle) menjadi indikator keberhasilan sambungan (Tirtawinata, 2003). Posisi pengambilan tunas batang atas dan posisi pemotongan tunas batang bawah sangat mempengaruhi keberhasilan grafting dan seterusnya dapat mempengaruhi kesesuaian (matching) lingkaran jaringan pembuluh gabungan. Apabila lingkaran jaringan pembuluh batang atas dan batang bawah kurang sesuai maka mengakibatkan pertumbuhan selanjutnya menjadi lambat, karena proses penggabungan sel-sel kedua batang terhambat, bahkan selanjutnya dapat mengakibatkan kegagalan proses grafting (Handayani et al., 2013).

Keberhasilan sambung juga sangat ditentukan oleh mekanisme kompatibilitas itu sendiri, misalnya sifat fisiologi, biokimia dan sistem anatomi secara bersamaan. Persaingan unsur hara juga terjadi apabila ada tumbuhan pengganggu. Ruang kosong yang diinvasi oleh berbagai jenis tumbuhan pengganggu akan menghambat pertumbuhan tanaman. Sifat mendominasi suatu spesies gulma tertentu dapat menimbulkan dampak buruk bagi ekosistem yang dapat menurunkan hasil tanaman.

Dengan demikian dapat diketahui bahwa adanya sambungan yang gagal tidak semata-mata disebabkan oleh perlakuan cara penyimpanan dan lama penyimpanan batang atas akan tetapi bisa disebabkan karena faktor lingkungan seperti kelembaban, cahaya ataupun suhu selain itu juga bisa disebabkan dari faktor teknis saat pelaksanaan sambung itu sendiri.

\section{KESIMPULAN}

1. Faktor cara penyimpanan batang atas (dibungkus dan tidak dibungkus koran) tidak 
memberikan pengaruh di semua peubah yang diamati.

2. Faktor lama penyimpanan batang atas berpengaruh terhadap pertumbuhan bibit durian hasil sambungan. Batang atas dapat disimpan paling lama hanya 2 hari. Semakin lama batang atas disimpan sebelum disambungkan, akan menurunkan tingkat keberhasilan sambungan.

3. Kombinasi perlakuan antara cara dan lama penyimpanan batang atas tidak memberikan pengaruh di semua peubah yang diamati.

\section{DAFTAR PUSTAKA}

Anindiawati, Y. 2011. Pengaruh Perlakuan Masa Penyimpanan dan Bahan Pembungkus Entres Terhadap Pertumbuhan Awal Bibit Jeruk (Citrus Sp.) Secara Okulasi. Skripsi. Fakultas Pertanian. Universitas Sebelas Maret. Surakarta. http://id.scribd.com/doc/225056386/skri psi-okulasi-pdf\#scribd. [02 Mei 2015]

Ermansyah. 2012. Pemanfaatan Mikoriza Vesikular Arbuskular (MVA) dan Berbagai Jenis Kompos Terhadap Pertumbuhan Bibit Sambung Pucuk Tanaman Kakao (Theopbroma cacao L.). [Skripsi]. Jurusan Budidaya Pertanian, Fakultas Pertanian Universitas Hasanuddin, Makassar.

Handayani, R.S., Poerwanto, R., Sobir, Purwito, A., Ermayanti, TM. 2013. Pengaruh Batang Bawah dan Jenis Tunas Pada Mikrograftting Manggis (Garcinia mangostana L.) Secara In Vitro. J. Agron. Indonesia. 41 (1) : 47-53.

Handayani R.S., Maisura, Rizki DA. 2017. Pengaruh Letak Posisi Eksplan dan Sitokinin Pada Perkecambahan Biji Manggis (Garcinia mangostana L.) Lokal Aceh Secara in-Vitro. Jurnal Agrium 14(2) $: 1-8$.

Handayani, R. S., \& Ismadi. 2017. Analisis Keragaman Kualitas Buah Durian Unggulan (Durio zibethinus) Aceh Utara. Jurnal Hortikultura Indonesia, 8(3), 147-154.

Handayani, R. S., \& Ismadi. 2018. Inventory and morphological characterization of durian (Durio zibethinus) in langkahan and sawang sub-district of north aceh indonesia. Emerald Reach Proceedings Series, 1, 601-
608.

Handayani, R. S., Ismadi, Sayuti, M., \& Irawan, E. 2019. In-vitro Callus Induction of Durian (Durio zibethinus Murr.) Leaves Using Kinetin and 2,4-D (Dichlorophenoxyacetic acid). Journal of Tropical Horticulture, 2(2), 59-64.

Ismadi, Handayani, R. S., Hafifah, \& Fahrezi, I. 2018. Exploration and morphological characterization of vegetative part of avocado at bebesan subdistrict central Aceh district, Indonesia. Emerald Reach Proceedings Series, 1, 60-73.

Ismadi, Handayani, R. S., Hafifah, \& Rahmiyati. 2019. Morphological diversity of avocados (Persea americana Mill.) in central Aceh, Indonesia. International Journal of Recent Technology and Engineering, 7(6), 14011405.

Jamnah, 1996. Pengaruh Lama Penyimpanan Bahan Batang Atas Terhadap Pertumbuhan Okulasi Durian (Durio zhiberthinus). [Skripsi]. Jurusan Budidaya Pertanian, Fakultas Pertanian, Universitas Borobudur, Jakarta.

Lasimin, S. 2009. Teknik Okulasi Bibit Durian Pada Stadia Entres dan Model Mata Tempel yang Berbeda. Jurnal Teknik Pertanian. 3 (4).

Manubelu.Y.S. 2011. Pengaruh Jenis Klon dan Lama Penyimpanan Entres Terhadap Pertumbuhan Sambung Samping Kakao ( Theobroma cacao L.) Pertanian Lahan Kering. [05 Mei 2015].

Rosyidah, O. 2010. Durian Si Raja Buah. Semua Tentang Aspek Budidaya. http://blog.djarumbeasiswaplus.org/rosyida h/2010/06/11/durian-si-raja-buah-semuatentang-aspek-budidaya. [15 Mei 2012].

Sjaefuddin, A. dan Abdurahman. 2001. Daya Simpan Batang Atas dan Penggunaan Media Pembungkusnya pada Tanaman Sirsak. Buletin Teknik Pertanian 6(1):26-28.

Sumarianto, P. 2012 Budidaya Tanaman Durian. Universitas Andi Djemma Palopo. http://vvbjgyiluyggliuygtuguyf.blogspot.co m/. [05 Mei 2015].

Tirtawinata MR. 2003. Kajian anatomi dan fisiologi sambungan bibit manggis dengan beberapa kerabat Clusiaceae [disertasi]. Bogor: Institut Pertanian Bogor, Program Pascasarjana. 171 hal. 